\title{
BoARd InClusion in FinANCIAL REPORTING AND DIVIDEND PoliCy: EVIDENCE FROM STATIC AND DYNAMIC PANel VAR MODELS
}

\author{
Yusuf Olatunji Oyedeko ${ }^{\star}{ }^{\star}$, Mohammed Zubairu $^{\mathrm{b}}$, Aruna Ishola Mamidu ${ }^{\mathrm{c}}$ \\ a. yusuf.oyedeko@fuoye.edu.ng, Department of Banking and Finance, Federal University Oye Ekiti, \\ Ekiti State, Nigeria. \\ b. zubairu3070@gmail.com, Department of Banking and Finance, Ahmadu Bello University, Zaria - \\ Nigeria. \\ c. mamiduarunaishola@gmail.com, Department of Accounting, Achievers University Owo-Ondo state
}

Received date: 22/ 12/2020, Accepted date: 30/ 01/2021, online publication date: 31/ 12/2021

\begin{abstract}
The study explored how board inclusion in financial reporting affects the dividend policy in Nigeria. The study was conducted within the context of deposit money banks (DMBs) and data were gathered from the financial statement of listed DMBs in Nigeria for ten years spanning from 2008 to 2017. The study employed static and dynamic panel VAR technique. The result showed that dividend per share can predicts frequency of the board meeting, the frequency of board meeting can predicts board compliance to banks' rules and regulation in the future and board compliance to banks' rules and regulation can predict dividend per share. The study concluded that board inclusion in financial reporting on dividend policy exerts longrun and short run negative effect on dividend policy. In view of this study recommended that the board inclusion in financial reporting should aim at discouraging manipulative accounting tendencies and enhance true fare of financial position of the banks with the goal of improving or maximising dividend policy represented by the amount of cash pay-out as dividend to shareholders as a form of reward for their investments.
\end{abstract}

Keyword: Board inclusion in financial reporting, dividend per share, Deposit money banks

JEL Code: G34, G35

\section{INTRODUCTION}

Corporate dividend policy is a trade-off between payment of dividend to shareholders and retained earnings for profitable investment opportunities. Payment of dividend represents cash flows out of the firm to shareholders while retained earnings are the internal source of financing the growth of a firm. This implies that dividend policy

\footnotetext{
^ Corresponding Author
} 
has significant effects on capital formation and adequacy, banks performance, future level of dividend payment as well as market valuation of the firm (Somoye, Akintoye \& Oseni, 2009). Evidence from the literatures have shown that this area of research is elusive and controversial because it varies over time among different firms and as such several theories such as irrelevant, relevant dividend theories among others have emerged to explain the conflicting issues and how it affects firms' value (Amidu, 2007). In the same view, Foong, Zakaria and Tan (2007) assert that there is significant relationship between dividend policy, future earnings and the cost of capital of banks. The reason is because equity investors are rational economic agents with expectations to receive more returns from their investments as dividends, while the ability of banks to pay dividend influences their financial performance.

In view of this, a growing number of studies have emerged in the literature and have focused on in examining the determinants of dividend policy across countries, industries and firms especially in the area of corporate governance. Some of these studies were documented as follow; Bokpin (2011) focused on insider ownership and dividend performance. They suggested that managerial ownership has potential to align the divergence of interest between the managers and the shareholders as well as improve dividend policy. More so, Subramaniam and Susela (2010) found that $\mathrm{c}$

orporate governance influence dividend policy in Malaysia. In addition, Alshabib and Ramesh (2011) documented that there is a relationship between board size and board independence and dividend policy in United Kingdom. In Ghana, Asamoah (2011) provided convincing evidence that corporate governance has negative influence on agency problem and positive influence on dividend policy. In United State of America, Gill and Obradovich (2012) affirmed that board size and board duality positive influence on dividend policy decision within the service firms. Abor (2013) conducted a comparative study and found that board size and board independence has influence on dividend policy in Kenya and Ghana while ownership structure influences dividend policy in South Africa.

In view of this, studies on the relationship between corporate governance and dividend policy remain inconclusive. However, many of these studies emphasised more on board structure ownership structure among others but it is however still unclear the extent to which board inclusion in financial reporting affects the dividend policy. Thus, the study examines the effect of board inclusion in financial reporting on dividend policy. In consonance with this objective, the proposed research question and hypothesis are ;

Research Question

what is the effect of board inclusion in financial reporting on dividend policy?

Hypothesis

Board inclusion in financial reporting has no significant effect on dividend policy.

Thus, the rest of the paper is organised in four sections. Section two reviewed literature on board inclusion in financial reporting and dividend policy, section three outlines the methodology adopted for the study. Data analysis and discussion were presented in section four while section five concludes the paper and proffer recommendations.

\section{LITERATURE REVIEW}

Board inclusion in financial reporting is an aspect of corporate governance which is captured by the extent of director involvement in financial reporting, board compliance to bank rules and regulation and frequency of board meeting. These 
variables interact to ensure that board members have detail information on the net worth of the banks which would help the board members in providing good leadership for the bank. Board involvement in financial reporting is number of directors present in the audit committee to total board size. The directors present in the audit committee are to provide information to other board members at the board meeting. Board compliance to banks' rules and regulation is measured by the frequency of time deposit money bank violate banks' rules and regulation. While frequency of board meeting is defined as the number of times the directors called for a meeting. These variables have not been adequately researched and this study bridges the gap in the literature. Dividend policy refers to the decision to distribute all or part of the company's profit in the form of dividends to the shareholders or plough a proportion of the company profit back to the business (Al-Malkawi, Rafferty \& Pillai, 2010). It is the practice usually adopts by the management in making dividend payout decisions or the amount of cash distributed over time to stockholders (Lease, Kose, Avner, Uri and Oded2000). Dividend policy represents an appropriation of profit to shareholder and guideline for paying certain proportion of earnings to investors as dividends (Marfo-Yiadom \& Agyei, 2011). The linkage between board inclusion in financial report and dividend policy is shown, in Figure 1 below:

Figure 1: Conceptual Model of Board Inclusion in financial Reporting and Dividend Policy

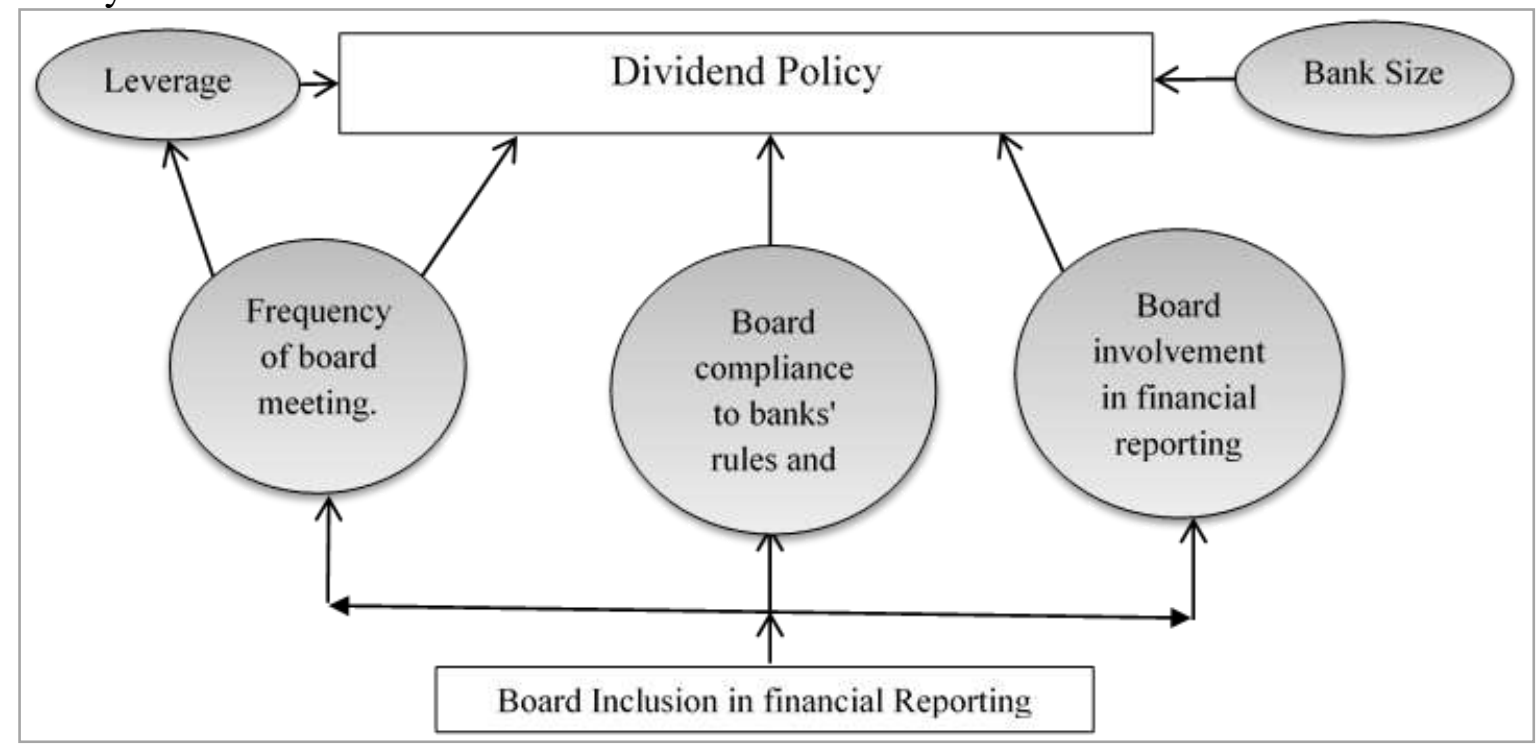

Source: Constructed by the Authors

In spite of this conceptual linkage some of the previous studies that have been documented as follow; Jirapon, Kim and Kim (2011) motivated by the agency theory, examine how corporate governance affects dividend policy. The study used a large sample of firms with governance data from the institutional shareholder services (ISS). The study used logistic regression for dichotomous and ordinary least square for non-dichotomous variable. The study documented that propensity to pay dividend has significant effect on corporate governance. The study concluded that, shareholders of firms with better governance quality are able to force managers to disgorge more cash through dividends, thereby reducing what is left for expropriation by opportunistic managers. In United Kingdom, Alshabib and Ramesh (2011) documented an empirical study on factors affecting dividend policy using 
data collected from 90 non-financial listed firms. The used Forecasting Analysis and Modelling Environment (FAME) and regression method to analyze the data. The study found that corporate governance mechanism such as board size and board independence influence dividend policy. In conclusion, evidence from the United Kingdom that board independence is primary determinants of dividend policy.

Adjaoud, Walid and Fatma (2012) proposed a study on the effect of board characteristics and ownership Structure on corporate dividend policy in Canada. The authors used dividend yield and decision to pay dividend as dependent variable. The findings revealed that external block-holders ownership has positive and significant effect on the decision to pay dividends. In addition, firm size and free cash flows are positively related to dividends policy decision. In 2012, Gill and Obradovich documented a study on the effect of corporate governance and institutional ownership on dividend policy decision in American service firms. The study gathered data from two hundred and ninety-six quoted firm in New York Stock Exchange (NYSE) spanning from 2009 to 2011. The data were analyzed through Ordinary Least Square (OLS) multiple regression and the findings revealed that board size and CEO duality have positive relationship with dividend policy whilenegative relationship exists between institutional ownership and dividend policy. Finding also revealed that no significant relationship was found between internationalization of firms and Industry classification.

In the same token, Thomas (2013) examined the relationship between board characteristic and dividend policy. The study employed board characteristic which comprises of board size, percentage of insider directors, percentage of women directors, ownership structure and directors tenure are measure against dividend policy. The study adopts regression analysis and it was found that board size has positive and significant influence on dividend policy while board independence negative but significant influence on dividend policy. The implication of this is that that board independence reduces agency problem. The study also documented that the percentage of share held by the directors is inconclusive. Iqbal (2013) carried out a study on influence of corporate governance on dividend policy in emerging economies. The study employed logistic and probit regressions as a tool data of analysis. The study revealed that board Size has positive and significant influence on dividend decision while board duality has positive but insignificant on dividend decision in Egypt, Malaysia, Pakistan and Iran. The finding also revealed that board independence, leverage and firm volatility have influence but negatively related with dividend decision of the firms. In conclusion, study supports the Agency Theory. Arshad, Akram, Amjad and Usman (2013) proposed a study on corporate governance and dividend policy among Pakistan firms. The gathered data from twelve quoted firms quoted on Karachi Stock Exchange for the duration of five years spanning from 2007 to 2011. The tool of analysis employed is regression analysis and it was revealed that board size relates positively but insignificant with the dividend policy decision. Thus further contradict findings in developed countries for their insignificant posture. However, the positive effect of return on equity on dividend policy confirmed that dividend policy has a significant effect in Pakistan. 
Abor (2013) carried out a study on effect of corporate governance on dividend policy in Sub-Saharan Africa countries of which 177 Nigerian firms spanning from 1997 to 2006. It was documented that corporate governance variables exhibit negative but significant effect on dividend policy. The study concluded that in Nigeria, improve corporate governance structure is associated with more retention of earning and low dividend payout in order to mitigate cost of external finance. However this study was too general, but did not specifically focus on the deposit money banks in Nigeria. Nwidobie (2013) did a study on agency conflict and corporate dividend policy decision in Nigeria. The study identified several independents variables such as profitability of the firm, cost of paying dividend, stability of earnings, prospects of raising funds from the capital market and shareholders characteristics. The study found that solutions to agency problems and past dissatisfactory behaviours of shareholders (complaints of shareholders) is not a determinant of current and future dividend decisions while the needs and desires of shareholders has negative effect on dividend paid by the firms. However the study emphasized on agency conflict but deviated in to conventional approach. In 2013, Uwuigbe investigated determinants of dividend policy among selected Nigerian firms. Data were sourced from annual reports for fifty quoted firms in the Nigerian stock exchange from 2006 to 2011. The study adopted the ordinary least square (OLS) data estimation method. It was revealed that board independence, financial performance, firm size positive effect on dividend policy. In conclusion, board independence affects dividend policy of deposit money banks in Nigeria.

Kurawa and Ishaku (2014) carried out a study on corporate governance and dividend policy of five commercial banks out of the 15 banks that were quoted on the Nigerian Stock Exchange from 2003 to 2012. The tool of analysis employed was panel regression and it was revealed that management equity holding has positive and significant relationship with dividend policy while board size and board duality also have positive but insignificant relationship with dividend policy. Board independence exhibits negative sign. The study concluded that corporate governance has effect on dividend policy. In most recent studies, Jahanzeb, Memon, Tunio, and Abbas Shah (2016) examined the relationship between board governance and corporate policy of listed companies in Malaysia. The found that board size, CEO ownership, growth and profitability remained significant whereas board independence and firm size remained insignificant. The study concluded that less agency cost issues are related to equity when CEO owns shares and that lesser growing companies and profitable companies are paying more dividends. Chen, Leung, and Goergen (2017) examined the relationship between female independent directors and high dividend payouts. The study found evidence that firms with a larger fraction of female directors on their board have greater dividend payouts. The study revealed that there exist positive relationship between board gender composition and dividends. The study concluded that board gender composition significantly increases the dividend payout only for firms with weak governance, suggesting that female directors use dividend payouts as a governance device. 
From the literature reviewed above, it is shown that none of the studies focused on board inclusion in financial reporting and this justify the need for this study in order to bridge the lacuna in the literature. Furthermore, virtually all the previous studies only employ static model in the specification of the dependent and independent variables but this study will significantly be different from the previous study by adopting both the static and dynamic model equation which will account for both short and long run effect of dependent variable on independent variable. Thus, in conducting this study stewardship theory will be adopted. This theory stresses that, stewards can cooperate and work closely with the principal to achieve a goal alignment (Davis, Schoorman, \& Donaldson, 1997). The theory diverges from selfinterest nature of the agents as hypothesised by the agency theory and places much trust and reliance on the agents which are the stewards of the organisation (Donaldson, 1990). In essence, stewards profit making for shareholders and this is in consonance with the finding of Abdullah and Valentine (2009) that stewards are satisfied and motivated when organization success is attained. Hence, stewards focus on the board's task and provide support and advice to the management for better performance but argue against managerial opportunity and emphasises on trust and achievement on the part of managers as both managers and owners have similar objectives (Davis, 1991).

The stewardship theory advocates that the board structure characterized with stewards is built on trust and elevated to the level of directors in order to protect the interest of the shareholders (Mallin, 2007). The figure 2, below illustrated the relationship between the shareholders and the directors.

Figure 2: Stewardship Relationships

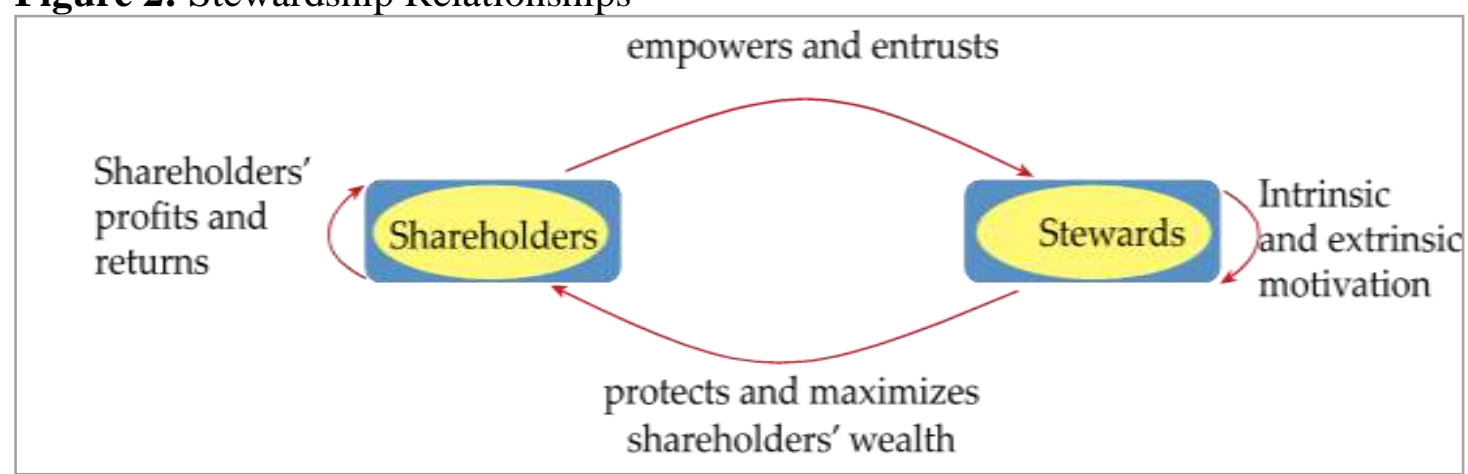

Source: Adapted from Fadare and Oyedeko (2018).

The figure 2, shows that the stewards are empowered by the shareholders in order to maximize the shareholders wealth. This is through enhancement of the profit and return of the firm. The shareholders also provide some intrinsic and extrinsic motivations in form of managerial perks to prevent the steward from succumb to self-interest opportunity behaviours which could fall short of the aspirations of the shareholders. This study is anchored on steward theory because board inclusion in financial reporting is expected to improve accuracy and true and fair financial position of banks and this will enhance dividend per share of the shareholders. 
Vol. 5, No. 2 (December 2021); ISSN: 2602-5655

\section{METHODOLOGY}

Expos-facto research design was used and the population of the study constitutes all the deposit money banks operating in Nigeria as 31st December, 2017 and sample were drawn through census sampling technique. Thus, the sample size of the study comprises of all 15 deposit money banks quoted on the Nigerian Stock Exchange as at 31st December, 2017. Data were collected on director involvement in financial reporting, board compliance to banks' rules and regulation, frequency of board meeting and dividend policy from the audited financial statements of the deposit money banks. The model specification for this study incorporates board inclusion in financial reporting variable and dividend policy variable. Board inclusion in financial reporting is captured by the extent of director involvement in financial reporting, board compliance to banks' rules and regulation and frequency of board meeting. The dependent variable proxy with dividend policy is captured by dividend per share. The model is specified under the static and dynamic frameworks. The former comprises the pooled, fixed and random effect regression model, while the latter deals with dynamic model similar to (Abrigo \& Love 2015). The models are specified below:

$$
\mathrm{dps}_{\mathrm{it}}=\infty_{0}+\infty_{1} \text { ndactds }_{\mathrm{it}}+\infty_{2} c f b m_{\mathrm{it}}+\infty_{3} b v r_{\mathrm{it}}+\varepsilon_{\mathrm{it}}
$$

Where dps is the dividend per share, ndactds is board involvement in financial reporting, cfbm is frequency of board meeting, bvrr is board compliance to banks' rule and regulation, leve is the leverage, bsz is the bank size, $\infty 1-\infty 5$ represent the coefficients of the variables, $\varepsilon$ represents the error term, $\infty 0$ represent the constant $i$ is the deposit money banks and $t$ is the time frame in the study and $\varepsilon$ is the idiosyncratic shock or individual observation error term.

Dynamic models for dividend per share and board inclusion in the financial reporting are specified below;

$$
\begin{aligned}
& \mathrm{dps}_{\mathrm{it}}=\infty_{01}+\infty_{11} \mathrm{dps}_{i t-1}+\ldots \infty_{1 p} \mathrm{dps}_{i t-p}+\infty_{12} \text { ndactbs }_{\mathrm{it}-1}+\ldots \lambda_{1 p} \text { ndactbs }_{i t-p}+ \\
& \infty_{13} c f b m_{\mathrm{it}-1}+\infty_{1 p} c f b m_{i t-p}+\infty_{14} b v r r_{\mathrm{it}-1}+\infty_{1 p} b v r_{\mathrm{it}-p}+f_{i}+d_{i}+\varepsilon_{\mathrm{it}} \\
& n d a c t b s_{\mathrm{it}}=\infty_{01}+\infty_{11} \mathrm{dps}_{i t-1}+\ldots \infty_{1 p} \mathrm{dps}_{i t-p}+\infty_{12} \text { ndactbs }_{\mathrm{it}-1}+\ldots \lambda_{1 p} \text { ndactbs }_{i t-p}+ \\
& \infty_{13} c f b m_{\mathrm{it}-1}+\infty_{1 p} c f b m_{i t-p}+\infty_{14} b v r r_{\mathrm{it}-1}+\infty_{1 p} b v r r_{\mathrm{it}-p}+f_{i}+d_{i}+\varepsilon_{\mathrm{it} 1} \\
& c f b m_{\mathrm{it}}=\infty_{01}+\infty_{11} \mathrm{dps}_{i t-1}+\ldots \infty_{1 p} \mathrm{dps}_{i t-p}+\infty_{12} \text { ndactbs }_{\mathrm{it}-1}+\ldots \lambda_{1 p} \text { ndactbs }_{i t-p}+ \\
& \infty_{13} c f b m_{\mathrm{it}-1}+\infty_{1 p} c f b m_{i t-p}+\infty_{14} b v r r_{\mathrm{it}-1}+\infty_{1 p} b v r r_{\mathrm{it}-p}+f_{i}+d_{i}+\varepsilon_{\mathrm{it} 1} \\
& b v r r_{\mathrm{it}}=\infty_{01}+\infty_{11} \mathrm{dps}_{i t-1}+\ldots \infty_{1 p} \mathrm{dps}_{i t-p}+\infty_{12} \text { ndactbs }_{\mathrm{it}-1}+\ldots \lambda_{1 p} \text { ndactbs }_{i t-p}+ \\
& \infty_{13} c f b m_{\mathrm{it}-1}+\infty_{1 p} c f b m_{i t-p}+\infty_{14} b v r r_{\mathrm{it}-1}+\infty_{1 p} b v r r_{\mathrm{it}-p}+f_{i}+d_{i}+\varepsilon_{\mathrm{it} 1}
\end{aligned}
$$

The a priori expectation for the models are dps $>0$, ndactds $>0$, cfbm $>0$ bvrr $>0$. The variables incorporated in the models specified above are measured in the Table 1.

Table 1: Measurement of Variables

\begin{tabular}{llllll}
\hline S/ & Variables & Types & Measurement & Sources \\
$\mathbf{N}$ & & & & \\
\hline $\mathbf{1}$ & Dividend Policy: & Dependent \\
Dividend per share & Variable & $\begin{array}{l}\text { Total dividend paid out Demeke (2016) } \\
\text { divided by number of } \\
\text { outstanding ordinary share } \\
\text { issued }\end{array}$ & \\
& & &
\end{tabular}


Board Inclusion in Financial Reporting and Dividend Policy...

\begin{tabular}{|c|c|c|c|c|}
\hline 2 & $\begin{array}{l}\text { Board Inclusion in } \\
\text { Fianaial reporting: } \\
\text { (1)Board in } \\
\text { involvement Board } \\
\text { financial reporting. } \\
\text { (2) Buliance to banks' } \\
\text { compliand regulation. } \\
\text { rules and } \\
\text { (3) Frequency of } \\
\text { board meeting. }\end{array}$ & $\begin{array}{l}\text { Independe } \\
\text { nt } \\
\text { Variable }\end{array}$ & $\begin{array}{l}\text { (1) Number of directors } \\
\text { present in the audit } \\
\text { committee to total board size } \\
\text { (2) Number of times deposit } \\
\text { money bank violate banks' } \\
\text { rules and regulation. } \\
\text { (3) Number of times the } \\
\text { directors called for a meeting }\end{array}$ & $\begin{array}{l}\text { Fadare and Oyedeko } \\
(2018) \\
\text { Vafeas } \\
\text { Farinha (2002) }\end{array}$ \\
\hline 3 & Bank Size & $\begin{array}{l}\text { Control } \\
\text { Variable }\end{array}$ & Logarithm of total assets & $\begin{array}{l}\text { Adesina, Nwidobie } \\
\text { and Adesina, (2015) }\end{array}$ \\
\hline 4 & Leverage & $\begin{array}{l}\text { Control } \\
\text { Variable }\end{array}$ & $\begin{array}{l}\text { Total debt divided by total } \\
\text { asset }\end{array}$ & $\begin{array}{l}\text { Khan, Naeem, } \\
\text { Rizwan, and Salman, } \\
\text { (2016) }\end{array}$ \\
\hline
\end{tabular}

Source: Authors' computation, (2018)

\section{RESULT AND DISCUSSION OF FINDINGS}

In this section, results of the descriptive and inferential statistics are presented. The descriptive statistics explains the behaviors of the data and their fitness for empirical analysis; while the inferential give information about the empirical investigation of the relationships between/among the specified variables. Thus, the descriptive comprises of mean, standard deviation, minimum and maximum values of the variable series and the summary of these statistics are presented in Table 2.

Table 2: Statistical Description of the Data

\begin{tabular}{clllc}
\hline Variable & Mean & Std. Dev. & Min & Max \\
\hline dps & .3680333 & .4681726 & 0 & 1.75 \\
ndactbs & .2315416 & .066999 & .15 & .5 \\
cfbm & .074857 & .4197983 & -.6363636 & 1.5 \\
bvrr & .3733333 & .4853099 & 0 & 1 \\
lev & 3.699467 & 17.9343 & -58.74 & 172.53 \\
bsz & 5.616065 & .7560986 & 2.3559 & 6.5429 \\
\hline
\end{tabular}

Note: dps, ndactbs, cfbm, bvrr, lev and bsz represents dividend per share, number of directors present in the audit committee to total board size, number of times the directors called for a meeting, number of times deposit money bank violate banks' rules and regulation, bank size and leverage respectively.

Source: Authors' computation, (2018)

The mean values of dps, ndactbs, cfbm, bvrr, leve and bsz are $.368, .232, .075$, $.373,3.700$ and 5.616 respectively. The common feature of these variables is that they all have positive mean values. This means that each of the variables displays increasing tendency throughout the sampling period. The mean value of dividend per share is approximately 0.37 and this overt that infinite-decimal proportion of the huge profit declared by banks is distributed to shareholders. The average value of board involvement in financial reporting, frequency of board meeting and board compliance to banks' rule and regulation manifest positive changes over time. Also, bank size and leverage show a positive change over the period of sampling period. The descriptive statistics also show that dividend per share ranges between 0 and 1.75 . This has explicitly revealed that there are cases dividends are not paid and the maximum dividend paid during the period of investigation is 1.75 naira per share. The dividend per share is the lowest volatile among the variables under investigation while the 
highest volatile is the leverage. The leverage value is very high as shown by the range from -58.74 to 172.53 and this implies that the capital structure of the deposit money banks composed more of leverage than equity. After the description of the variable, the next step is to look at the inferential statistics which is based on regressions. Since regression results may turn out to be spurious, if the fitted data series are not checked for stationarity. Therefore, in carrying out the inferential analysis of the proposed relationships, the study, first test for stationarity using Harris-Tzavalis technique. The result is reported in Table 3 .

Table 3: Harris-Tzavalis Unit Root Test

\begin{tabular}{lccl}
\hline Variable-Series & HT-Stat & Z-Stat & P-Value \\
\hline dps & 0.3879 & -4.7683 & 0.0000 \\
ndactbs & 0.4129 & -4.4168 & 0.0000 \\
cfbm & -0.2635 & -13.9200 & 0.0000 \\
bvrr & 0.1944 & -7.4864 & 0.0000 \\
lev & 0.0305 & -9.7892 & 0.0000 \\
bsz & 0.5184 & -2.9352 & 0.0017 \\
\hline
\end{tabular}

Source: Authors' computation, (2018)

It is explicit from the table that Harris-Tzavalis statistics are larger than the critical $\mathrm{z}$ statistics and this is supported by the probability values which are respectively less than the alpha value at 5 percent. This suggests that the null hypothesis of panels unit root is rejected with 95 percent confidence. This implies that the panels do not contain unit root and all the variables are stationary at level and the variables can be fitted into models stated in section three for onward estimation. Theoretically, three models are proposed to be estimated: the pooled regression, fixed effects and random effects models. These three models cannot be estimated at the same time for each block. Therefore, in each case, there is need to test the random against the pooled; and then the random against the fixed. Having confirmed the stationarily of the variables, the next step is to conduct a diagnostic test in order to estimate and interpret the model that is suitable for our study. The result of the diagnostic is reported in Table 4.

Table 4: Diagnostic Test

\begin{tabular}{lll}
\hline & Statistic & Value \\
\hline Panel A: BP LM & chibar2(01) & 177.60 \\
& Prob > chibar2 & 0.0000 \\
Panel B: Hausman Test & chi2(2) & 3.95 \\
& Prob>chi2 & 0.1390 \\
\hline
\end{tabular}

Source: Authors' computation, (2018)

The test of the random effects model against the pooled regression model is conducted using Breusch and Pagan Lagrangian multiplier test. The results show that the test statistics is asymptotically large with 0 percent probability value and this implies that at alpha value of 5 percent the null hypothesis that there are no panel effects is rejected. This suggests that random effects model appears to be more adequate or robust than the pooled regression model. To have a firm robust test, the researcher also tests the random effects against the fixed effects using hausman test. As indicated in the table 4the test statistics are abysmally small and associated with 
large probability value of 0.1190 . Thus, given the alpha value at 0.05 , the null hypothesis that the individual effects do not correlate with the included variables cannot be rejected. This implies that the random effects model has appeared again to be more adequate than the fixed effects model. The study therefore proceeds to estimate the random effects model.

Table 5: Regression Result (Dependent variable: Dividend Per Share)

\begin{tabular}{lllll}
\hline Variables & Coef. & Std. Err. & $\mathrm{z}$ & $\mathrm{P}>|\mathrm{z}|$ \\
\hline ndactbs & -.5689867 & .4470631 & -1.27 & 0.203 \\
cfbm & .0286318 & .0611638 & 0.47 & 0.640 \\
bvrr & .019509 & .0566167 & 0.34 & 0.730 \\
bsz & -.0512634 & .0487696 & -1.05 & 0.293 \\
lev & .2232586 & .2622376 & 0.85 & 0.395 \\
cons & .5995504 & .3558733 & 1.68 & 0.092 \\
R-sq: & 0.1759 & & & \\
Wald chi2(5) & 3.19 & & & \\
Prob > chi2 & 0.6708 & & &
\end{tabular}

Source: Authors' computation, (2018)

From the result, it is shown that board involvement in financial reporting and bank size have negative and insignificant effect on dividend per share while Board compliance to banks' rules, regulation and frequency of board meeting and leverage have positive but insignificant effect on dividend per share of deposit money banks in Nigeria. Also, the coefficient of determination reveals that 17.59 per cent variation in dividend per share can be explained by board involvement in financial reporting, Board compliance to banks' rules, regulation, bank size and frequency of board meeting and leverage. The wald chi-square is 31.20 with associated probability-value of 0.6708 and this implies that the null hypothesis that all of the coefficients are jointly zero should be rejected. Thus, it can be deduced that meaningful generalization cannot be drawn from it. This is in consonance with z-statistic of individual variables as none of the variable is significant at 5 percent. To address the shortcoming of this study, the study estimates the dynamic panel specifications. The results are detailed in the tables below. Since these specifications are dynamic, there is need to select their optimal lag time or length. The study accomplishes this, using modified akaike information criterion, modified Schwarz information criterion and modified Hanna Quinn information criterion. Table 6 shows the results of optimum lag selection criterion.

Table 6: Optimal Lag Selection Criterion for the Specified Variables

\begin{tabular}{rllllll}
\hline lag & CD & J & J pvalue & MBIC & \multicolumn{1}{c}{ MAIC } & \multicolumn{1}{c}{ MQIC } \\
\hline 1 & .8479296 & 45.51212 & .5753601 & -161.7273 & -50.48788 & 94.90457 \\
2 & .91046 & 30.48074 & .543483 & -107.6789 & -33.51926 & -63.13039 \\
3 & .881987 & 14.38011 & .5704194 & -54.6997 & -17.61989 & -32.42545 \\
\hline
\end{tabular}

Note: modified akaike information criterion=maic; modified Bayesian information criterion=mbic; and modified Hanna Quinn information criterion=mqic; the decision rule is that the optimum lag is one that associates with the smallest statistical value

Source: Authors' computation, (2018)

The result of the modified information criteria in respect of the specified model is presented in table 4.5. The smallest statistics give the optimum or maximum lag 
length. A virtual view shows that the smallest maic, mbic and mqic statistics traced to lag one. In view of this, lag one is selected by the modified akaike information criterion, modified Bayesian information criterion and modified Hanna Quinn information criterion as the optimum lag for the model specified. The panel VAR approach is restricted to lag one. Thus, the study estimated panel VAR using Generalized Method of Moment (GMM). Table 7 provides the summarized results.

Table 7: Showing the Results of the Interrelationship between dps, ndactbs, cfbm, and bvrr,

\begin{tabular}{lllll}
\hline Variable & Coef. & Std. Err. & $\mathrm{z}$ & $\mathrm{P}>|\mathrm{z}|$ \\
\hline Panel A: dps & & & & \\
dps (-1) & .0965918 & .0869769 & 1.11 & 0.267 \\
ndactbs(-1) & -.6273204 & .4493087 & -1.40 & 0.163 \\
cfbm(-1) & -.0694589 & .0263384 & -2.64 & 0.008 \\
bvrr (-1) & -.0170694 & .0252576 & -0.68 & 0.499 \\
Panel B: ndactbs & & & & \\
dps(-1) & .0007065 & .0093366 & 0.08 & 0.940 \\
ndactbs(-1) & .6145825 & .0873397 & 7.04 & 0.000 \\
cfbm(-1) & .0079903 & .0054614 & 1.46 & 0.143 \\
bvrr(-1) & -.0025333 & .0034507 & -0.73 & 0.463 \\
Panel C: cfbm & & & & \\
dps (-1) & -.0531135 & .1763606 & -0.30 & 0.763 \\
ndactbs(-1) & .8342703 & .6981071 & 1.20 & 0.232 \\
cfbm(-1) & -.2656617 & .0557947 & -4.76 & 0.000 \\
bvrr(-1) & .1324228 & .0496214 & 2.67 & 0.008 \\
Panel D: bvrr & & & & \\
dps(-1) & .4397619 & .174074 & 2.53 & 0.012 \\
ndactbs(-1) & -4.152828 & .7045556 & -5.89 & 0.000 \\
cfbm(-1) & -.0353845 & .0685413 & -0.52 & 0.606 \\
bvrr & .5718916 & .0662277 & 8.64 & 0.000 \\
\hline
\end{tabular}

Source: Authors' computation, (2018)

The results of the interrelationship between dividends per share, board involvement in financial reporting, board compliance to banks' rules and regulation and frequency of board meeting are shown in table 7 . This provides a test on the hypothesis that there is dynamic relationship between these variables. It is revealed in panel A; that the lag one value of board involvement in financial reporting and frequency of board meeting maintain inverse and insignificant relationship with dividend per share; while lag one value of Board compliance to banks' rules and regulation has negative but significant relationship with dividend per share. Also, the panel reveal that the lag one value of dividend per share has positive but insignificant relationship with dividend per share. This means current income of shareholders is positively influenced by immediately previous value of dividend distributed to shareholder while board involvement in financial reporting, board compliance to banks' rules and regulation and frequency of board meeting negatively influenced the current income of shareholders. This revealed to the management of banks in Nigeria that the board inclusion in the financial reporting do affect the present income or wealth of banks' shareholders. Panel B reveals that current value of board involvement in financial reporting is positively influenced by immediately previous value of dividend per share, board involvement in financial reporting, and frequency 
of board meeting, while bank compliance to rules and regulation maintain positive influence on current value of board involvement. Also, it was revealed that previous value of board involvement has a significant influence on the current value of board involvement in financial reporting and this implies that an increase in the number of director in audit committee will improve the quality of financial reporting. In panel C, it is discovered that any increase in the previous value of frequency of board meeting and dividend per share decreases current value of frequency of board meeting but previous value of board compliance to banks' rules and regulation and board involvement in financial reporting are found to be positive determinant of current value of frequency of board meeting. In panel $\mathrm{D}$, the study establishes that current value of board compliance to banks' rules and regulation is positively influenced by previous dividend per share and board compliance to banks' rules and regulation. However, the current value of board compliance to banks' rules and regulation could increase as a result of decrease in previous value of board involvement in financial reporting and frequency of board meeting. The study equally examines cause and effect; between each pair of the variables in the model using the popular Granger causality technique. The results are shown in Table 8.

Table 8: Showing the Results of the Granger Causality between Pair of dps, ndactbs, cfbm, and bvrr

\begin{tabular}{cccc}
\hline Equation $\backslash$ Excluded & chi2 & df & Prob > chi2 \\
\hline Panel A: dps & & & \\
ndactbs & 1.949 & 1 & 0.163 \\
cfbm & 6.955 & 1 & 0.008 \\
bvrr & 0.457 & 1 & 0.499 \\
ALL & 11.102 & 3 & 0.011
\end{tabular}

Panel B: ndactbs

$\begin{array}{llll}\text { dps } & 0.006 & 1 & 0.940 \\ \text { cfbm } & 2.141 & 1 & 0.143 \\ \text { bvrr } & 0.539 & 1 & 0.463 \\ \text { ALL } & 3.829 & 3 & 0.281\end{array}$

Panel C: cfbm

$\begin{array}{cccc}\text { dps } & 0.091 & 1 & 0.763 \\ \text { ndactbs } & 1.428 & 1 & 0.232 \\ \text { bvrr } & 7.122 & 1 & 0.008 \\ \text { ALL } & 9.021 & 3 & 0.029\end{array}$

Panel D: bvrr

$\begin{array}{llll}\text { dps } & 6.382 & 1 & 0.012 \\ \text { ndactbs } & 34.742 & 1 & 0.000 \\ \text { cfbm } & 0.267 & 1 & 0.606 \\ \text { ALL } & 58.887 & 3 & 0.000\end{array}$

Source: Authors' computation, (2018)

The study conducts a Wald test to examine the Granger causality between the pair of variables in the model specification. The test results are summarized in table 4.7 in four compartments. In the first compartment, all p-values are insignificant except in the case of frequency in the board meeting and this implies that frequency of the board meeting granger cause dividend per share. Thus, it means dividend per share can be used in predicting frequency in the board meeting but cannot explain board involvement in financial reporting and board compliance to banks' rules and 
regulation. The p-values in the second compartments are insignificant and this implies that board involvement in financial reporting cannot explain dividend per share, frequency in the board meeting and board compliance to banks' rules and regulation. In the third compartment, all the p-values are insignificants except board compliance to banks' rules and regulation. This implies that the null hypothesis that the excluded variable does Granger cause equation variable is rejected with 95 percent confidence for board compliance to banks' rules and regulation. In the fourth compartment all the p-values are insignificant except in board involvement in financial reporting. Board compliance to banks' rules and regulation appears to be a useful tool for predicting board involvement in financial reporting but cannot predict dividend per share and frequency in the board meeting in the future. The researcher further investigates the persistence and decaying of shocks in the system using impulse response functions analysis. The result is shown in figure 3, below:

Figure 3: Impulse Response Analysis of a Set of Variables dps, ndactbs, cfbm, and bvrr
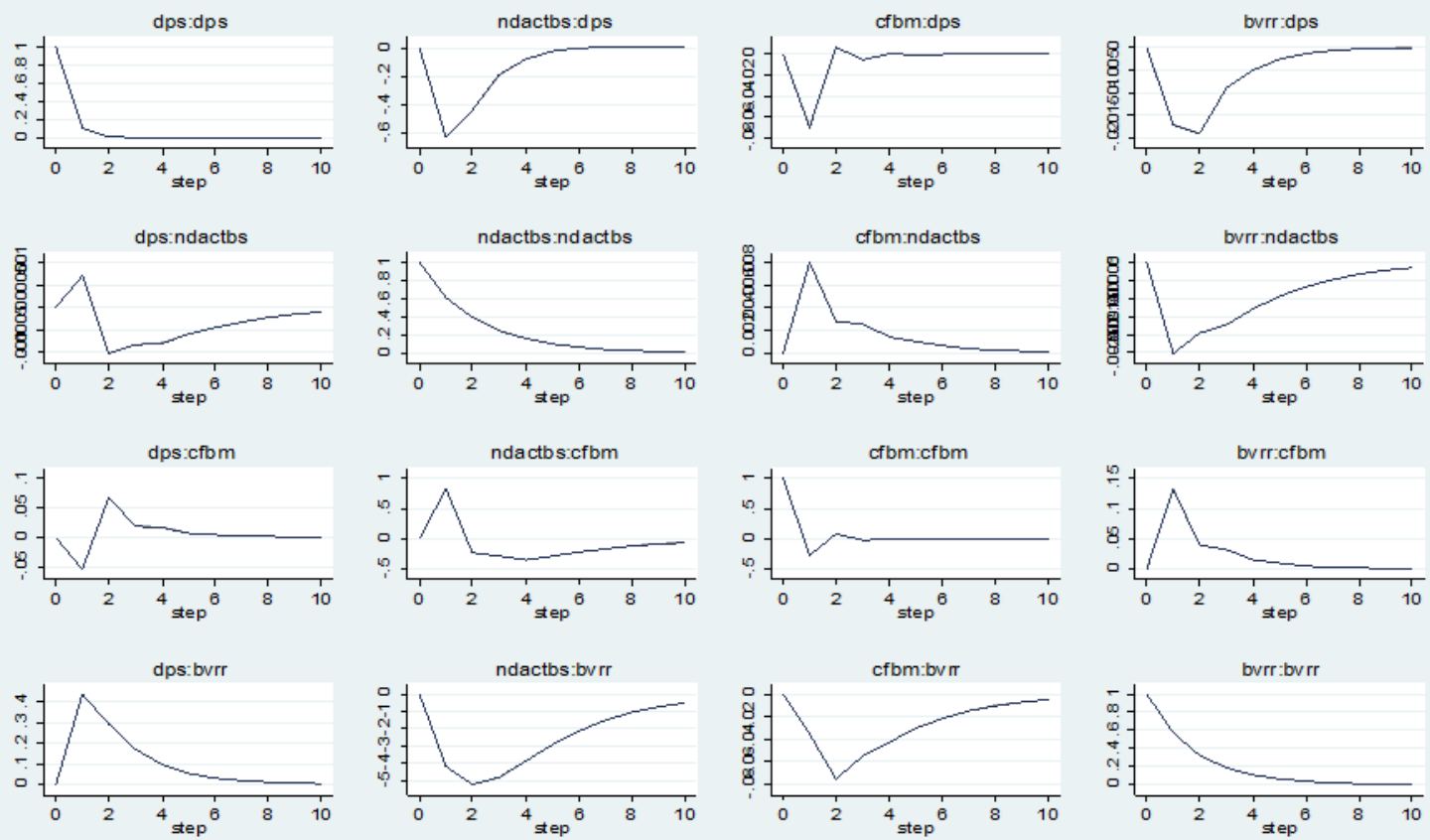

impulse variable: response variable

The first set of graphs shows the response of dividend to itself, board involvement in financial reporting, frequency of board meeting and board compliance to banks' rules and regulation. In this set of graphs, the first curve shows the shocks of dividend to itself and dividend to board compliance to banks' rules and regulation finally rest on zero meaning that the current changes of dividend to itself and board compliance to banks' rules and regulation will not persist for a long time. The shocks of board involvement in financial reporting and frequency of board meeting do not come to zero, implying that the shocks of dividend to board involvement in financial reporting and frequency of board meeting persist for a long time or infinitely. The second set of graphs indicates the response of board involvement in financial reporting itself, dividend per share, frequency of board meeting and board compliance to banks' rules and regulation. It can be seen that except in respect of board involvement in financial reporting, the curves do not rest at zero. It means the shocks 
of dividend per share, frequency of board meeting and board compliance to banks' rules and regulation to board involvement in financial reporting prolong indefinitely. Third set of graphs reveals the response of frequency of board meeting to itself, dividend per share, board involvement in financial reporting and board compliance to banks' rules and regulation. The curves of these graphs do not decay to zero except in the case of board involvement in financial reporting to frequency of board meeting. Finally, in fourth set of graph, the curve showing the response of board compliance to banks' rules and regulation to itself and frequency of board meeting decay to zero while in the other two cases it does not. This suggests that shocks of board compliance to banks' rules and regulation to dividend per share and board involvement in financial reporting persist for a long time. The model estimated needs to be diagolized by checking for it stability or otherwise. The results of the diagolized test are reported in table 8 and figure 4.2 respectively. Thus, the model estimated needs to be diagolized by checking for it stability or otherwise. The results of the diagolized test are reported in Table 8 .

Table 8: Diagolized Test Result on Panel VAR Model

\begin{tabular}{lcc}
\hline Real & Imaginary & Modulus \\
\hline .6738061 & 0 & .6738061 \\
.4896071 & 0 & .4896071 \\
-.2929694 & 0 & .2929694 \\
.1469605 & 0 & .1469605 \\
\hline
\end{tabular}

Source: Authors' computation, (2018)

From the table above, all the eigenvalues lie inside the unit circle and this onfirmed by the modulus values which are less than one. This implies that panel var satisfies stability condition. The graph reported in figure 4 below also show the visual evidence that none of the modulus/Eigen value is greater than one and this means the model is stable.

Figure 4: Showing the Invertibility of Panel VAR-Model One polynomial Roots

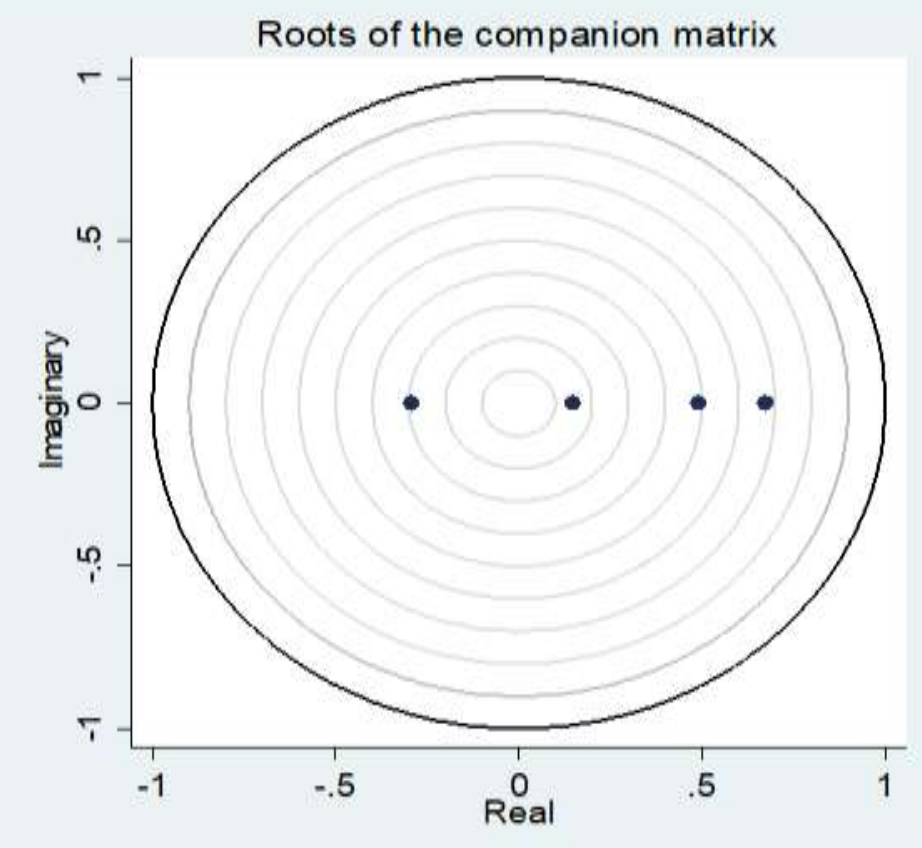


The interpretation of the panel VAR process is stationary or mean invertible. This implies that diagolized test result strongly adheres to theoretical expectation.

\subsection{Discussion of Result}

The study found short run the dynamic changes in the previous value of dividend per share could lead to positive changes in the present dividend per share and while previous values of board involvement in financial reporting, board compliance to banks' rules and regulation and frequency of board meeting have negative effect on dividend per share. The granger causality shows that dividend per share can be used in predicting frequency of the board meeting, the frequency of board meeting can be used in predicting board compliance to banks' rules and regulation in the future and board compliance to banks' rules and regulation can be used in predicting dividend per share. The study supports the findings of Vafeas (2003) who documented that there was a negative relationship between frequency of board meeting and dividend policy. This contradicts a priori expectation as frequency of the board meeting supposed to minimise the agency problem and improve the dividend policy. The explanation for this could be a result of the fact that times and effort of board of director devoted for meeting is not for the interest of the shareholders but for their personal interests. Thus, this is in consonance with the agency theory. The result of the study shows that there exist negative relationship between board involvement in financial reporting and dividend policy and this is in consonance with the finding of Fadare and Oyedeko (2018). This also does not conform to the apriori expectation and the explanation for this could be as a result of that fact board involvement in financial reporting might hinder true disclosure of financial position of the banks and this will affect the dividend policy of the banks. Also, the negative relationship between board compliance to banks' rules and regulation and dividend policy support the findings of Farinha (2002). This explained rules and regulations in deposit money banks are better monitored as part of internal corporate governance but it does not complement dividend per share.

\section{CONCLUSION AND RECOMMENDATION}

This study uses the static and dynamic models to examine the effect of board inclusion in financial reporting on dividend policy for the period of 2008 to 2017 . Findings from the study showThe study concluded that board inclusion in financial reporting on dividend policy exerts long-run and short run negative effect on dividend policy. In view of this study recommends that the board inclusion in financial reporting should aim at discouraging manipulative accounting tendencies and enhance true fare of financial position of the banks with the goal of improving or maximising dividend policy represented by the amount of cash pay-out as dividend to shareholders as a form of reward for their investments. One of the limitations of this study is that it focused only on banking sector, thus other studies can be conducted in other sectors in order to bridge the gap in the literature. 


\section{REFERENCES}

Abdallah, H., \&Valentine, B. (2000). Fundamentals of ethics theories of corporate governance. Middle Eastern Finance and Economics, 4, 88-96.

Abor, J. (2013). Does corporate governance explain dividend policy in Sub Saharan

Africa. International Journal of Law and Management, 55(3), 201-

225.

Abrigo, M. R. M., \& Love, I. (2015). Estimation of panel vector autoregression in Stata: a Package of Programs. 21 $1^{\text {st }}$ International Panel Data STATA Conference, Budapest, Hungary.

Adesina, J. B., Nwidobie, B. M., \& Adesina, O. O. (2015). Capital structure and financial performance in Nigeria. International Journal of Business and Social Research, 05(02), 21-31.

Adjaoud, F., Walid, B. A., \& Fatima, S. (2012). The impact of board characteristics and ownership structures on corporate dividend policy in Canada. Journal of International Finance Studies, 12(4), 5-18.

Al Shabibi, B. K., \& Ramesh, G. (2011). An empirical study of the determinants of dividend policy in the U.K. International Research Journal of Finance and Economics, 80, 105-120.

Amidu, M. (2007). How does dividend policy affect performance of the firm on Ghana stock exchange? Investment Management and Financial Innovation, 4(2), 103-112.

Asamoah, N. G. (2011).Corporate governance and dividend policy:An evidence from Ghana. Science Research Network, 1-22

Bokpin, G. A. (2011).Ownership structure, corporate governance and dividend performance on the Ghana Stock Exchange. Journal of Applied Accounting Research. 12(1), 61-73.

Chen, J., Leung, W., S., \& Goergen, M., (2017). The impact of board gender composition on dividend payouts. Journal of Corporate Finance 43, 86-105

Davis, J. H. (1991). Board leadership roles and shareholder returns: an examination of agency, Doctoral Dissertation, The University of Iowa.

Davis, J. H., Schoorman,\& Donaldson, L. (1997). Toward a stewardship theory of management. Academy of Management Review. 22, 20-37.

Donaldson, L. (1990) .The ethereal hand: organizational economics and management theory. Academy of Management Review.15(3), 369381.

Fadare, M. A., \& Oyede ko, Y. O. (2018). Corporate governance and corporate performance:

Lessons from pre and post adoption of international financial reporting standards in

Nigeria, Saudi Journal of Economics and Finance, 2(3), 70-76

Farinha, J. (2002). Dividend policy, corporate governance and the managerial entrenchment hypothesis: an empirical analysis. Journal of Business Finance and Accounting, 30 (9/10), 1173-1209. 
Vol. 5, No. 2 (December 2021); ISSN: 2602-5655

Foong, S. S., Zakaria, N. B., \& Tan, H. B. (2007). Firm performance and dividend related factors. The case of Malaysia, Labuan Bulletin of International Business and Finance. 5.

Gill, S., \& Obradovich, D. J. (2012). Corporate governance, institutional ownership, and the decision to pay the amount of dividends: evidence from USA. International Research Journal of Finance and Economics, 97, 60-71.

Iqbal, S. (2013).The impact of corporate governance on dividend decision of firms: evidence from Pakistan. African Journal of Business Management,7(11), 811-817.

Jahanzeb, A., Memon, P., A., Tunio, J., A., \& Abbas Shah S. S. (2016). Impact of corporate governance and firm-level control variables on dividend policy of

Development, service trade sector of Malaysia, Journal of Economic and Social $3(2)$.

Jiraporn, P., Kim, Y., \& Kim, J. (2011). Dividend policy and corporate governance quality: evidence from ISS. The Financial Review. 46, 251-279.

Khan, M. N., Naeem, M. U., Rizwan, M. \& Salman, M. (2016). Factors affecting the firm dividend policy: Empirical evidence from Textile sector of Pakistan, International Journal of Advanced Scientific Research \& Management, 1(5).

Kurawa, J. M., \& Ishaku A. (2014) . The effect of corporate governance on dividend policy of listed banks in Nigeria: A panel data analysis. Research journal's Journal of Finance. 2, (8), 1-12.

Mallin, C. A. (2007). Corporate governance. Second Edition, Oxford University Press.

Nwidobie, B. M. (2013). Agency conflict and corporate dividend policy decisions in Nigeria. Asia Economic and Financial Review. 3,(8), 1110-1121

Somoye, R.O.C., Akintoye I., \& Oseni, J. E. (2009). A model for pricing of equity in an environment characterized by information asymmetry: a case of emerging market. European Journal of Scientific Research, 29 (3), 426-443

Subramanniam, R., \& Susela, D. S. (2010) .Corporate governance and dividend policy inMalaysia. International Conference on Business and Economy Research, 1, 200-207.

Thomas, V. P. (2013). The effect of board characteristics on dividend policy. Department of Finance, Tilburg School of Economics and Management. 1-62.

Uwuigbe, U. (2013). Determinants of dividend policy: a study of selected firms in Nigeria. Journal of Leadership Manager. 17, 117 -119. 